\title{
MILK QUALITY OF PROPERTIES WITH DIFFERENT TECHNOLOGICAL STANDARDS
}

\author{
QUALIDADE DO LEITE DE PROPRIEDADES COM DIFERENTES PADRÕES \\ TECNOLÓGICOS
}

\section{Lenilson da Fonseca ROZA; Leandro Sâmia LOPES²; Flávio José SIMIONI³; Aleksandro Schafer da SILVA²; Evandro Paulo SCHONELL ${ }^{4}$; José Rodolfo Reis de CARVALHO}

1. Zootecnista, Mestrando em Zootecnia. Universidade do Estado de Santa Catarina - UDESC/CEO, Chapecó, SC, Brasil. lenilsonfonseca.zootecnista@ hotmail.com; 2. Doutor, Professor do Departamento de Zootecnia - UDESC/CEO, Chapecó, SC, Brasil; 3. Doutor, Professor do Departamento de Engenharia Ambiental - UDESC/CAV, Lages, SC, Brasil. 4. Zootecnista, Mestrando em Zootecnia. Universidade do Estado de São Paulo - USP, campus Luiz de Queiroz. Piracicaba, SP, Brasil; 5. Doutor em Zootecnia, Professor do Departamento de Zootecnia - UFSJ, São João Del-Rei, MG, Brasil.

\begin{abstract}
This study aimed to assess the parameters of milk quality of properties with different technological standards. Twenty five properties were analyzed from 7 countries from the West of Santa Catarina, and classified according to production technologies (feeding, breeding and management practices in general), capital used in the activity, technological standard of machinery, equipment and infrastructure. Ten properties were classified as low technological standard, 8 intermediate standard and 7 high technological standard. The milk's quality data of each property (fat, protein, somatic cell count (SCC) and total bacterial count (TBC)) were supplied by dairy products, being used the average of the months of February, March and April of 2013. The data was subjected to multivariate statistical analysis and variance. It was found that the properties of low technological standard had higher fat content in milk, followed by intermediate and high standard which didn't differ. The protein contents were higher in the properties of low standard with relation to intermediate standard, being that the high-tech standard didn't differ from the other groups. With regard to TBC, the properties of low-tech showed higher values when compared to the other groups, while the SCC did not differ between the different technological standards. We concluded that the technological standard of the properties influenced the parameters of protein, fat and TBC, being that in according with increased of the level of technological of properties, there was a decrease in these parameters, except that SCC didn't show the same behavior, not being influenced by technological standards. The percentage variations in milk protein and fat were explained by racial pattern of the animals and the amount of concentrate supplied to the animals. The TBC was influenced by the milking hygiene practices, such as milking system's pre-disinfection and the use of hot water in the sanitation of the equipment.
\end{abstract}

KEYWORDS: Dairy Cattle. Production Technologies.

\section{INTRODUCTION}

There is a growing concern of the consumer market and of the entire chain by dairy milk quality. This is due to economic losses and by the risk that poor quality milk can have on public health. By quality milk, it is understood as one whose chemical composition (fat, protein, lactose), microbiological, organoleptic (taste, appearance, and odor) and the number of somatic cells are within the parameters of quality demanded internationally (RIBEIRO; STUMPF JUNIOR; BUSS, 2000).

Currently, the requirement of minimum quality parameters are based on the Normative Instruction 62 of December 29, 2011 from Ministry of Agriculture, Livestock and Supply of Brazil, along with the increase in programs of payment by quality of milk, made with that increase, on producers side, the search for improved the quality of the milk produced in the properties. In milk chain, the most important step to improve the quality of the milk occurs precisely in dairy farms, because they are inherent to the main factors that influence it, such as handling, milking and herd sanity, power supplies and the racial pattern of animals (OHI et al., 2010).

In the West region of Santa Catarina, one of the peculiar characteristics of milk production is the great heterogeneity of the properties, which vary from systems with modern productive technologies (infrastructure, equipment, handling practices) to systems considered low-tech. In systems of low technology, the improvement of zootechnical indexes and the milk quality are major challenges to be faced. In the case of milk quality, the heterogeneity between properties makes complex assignment of what are the factors that influence the parameters of the milk. From this arises the need to understand the systems individually and detect what are the critical points to be worked by the producers as a way of improving the indices of milk quality. 
Considering the above, this study aimed to evaluate the parameters of milk quality of properties of the region West of Santa Catarina with different technological standards and diagnose what the main variables that influenced the quality of the milk.

\section{MATERIAL AND METHODS}

The study was carried out in the Western mesoregion of the State of Santa Catarina, in municipalities of Chapecó, Guatambu, Nova Itaberaba, Nova Erechim, Quilombo, Riqueza e Cunha Porã. The information collection occurred through visits to properties, between the months of February, March and April of 2013. To obtain data, a structured questionnaire was used, in which the interviewees were landowners or other family members who worked in the property management. In this way, was used the systematization proposed by Oliveira, Cunha e Campos (2007), concerning the general characterization of the property, participation of milk activity in property's income, the managements performed (handling milking, feeding and reproductive), quality of produced milk, among others.

Were evaluated 25 dairy properties, chosen according to the accessibility criteria. It is a nonprobabilistic sample, because it was random and self generated, i.e. it started from the indication of potential interviewees and grew successively from new indications (MATTAR, 2001). The properties were classified in 3 (three) technological standards, such: low, medium and high technological standards.

Starting from database disposed in electronic spreadsheets, the classification of the properties in homogeneous groups took place. For that, methodology was proceeded used by Lopes et al. (2009), which took in consideration production technologies (practiced in the area of the present study), such as alimentary handling, reproductive management, the genetic pattern of the animals and the technological relevance, diversity, current value and state of conservation of the exploration capital (improvements, machines, implements). Also considered in the classification were the technologies used in the extraction (type of milking) and storage of the milk (type of milk refrigerator).

Of the 25 properties analyzed, seven were classified as high technological standard, which were all of the free stall system. Thus, the properties framed in this group had high capital invested in facilities, machinery, equipment and implements intended for milk activity. The premises of these properties were predominantly of masonry and/or metal structure, being that all had shed for stock of inputs, supply room with metal, containing the milk room, waiting room (covered in asbestos cement and with paved floor), fish spine type milking parlor, with moat and ceramic coated. It stands out that the majority of installations and equipment had less than four years of use. Also they had a greater diversity of capital (greater number of leasehold improvements, machinery and equipment) and technological relevance (degree of modernization) of these capitals. All this group owners used artificial insemination as reproductive technology and performing the selection as a tool for genetic improvement. The animals of this technological standard were confined and received type power total diet. The herds were composed of specialized Jersey and Holstein breed.

For obtaining milk these properties had exclusive use of milking machines, which had modern technology adjunct in the system, such as automatic puller, individual pressure controller, production measurement, and electrical milk conductivity. All the properties had refrigeration equipment of milk type expansion and had water heater equipment (with temperature control) for sanitization of milking machine and utensils.

The group of low technological standard was composed of ten properties. Unlike the properties of high technological standard, they had low capital invested in leasehold improvements, machinery, equipment and implements. Also they had, less sophisticated machinery and equipment. The premises of these properties were simple and small, predominant wooden structures that had little room for feeding, the milk room, waiting room and shed for stock. In most properties, the milking parlor had no gap.

Regarding reproductive technologies, only two properties used artificial insemination, being that eight used bull for breeding. In this way, they had less specialized animals, predominantly mestizo, originated from crosses without adoption of genetic improvement tools. The feeding was pasture-based, with little or no supplementation of concentrates and/or silage. In most cases, the supplementation was performed only in periods of food shortage. Regarding technology used for milk extraction, eight properties possessed milking machines type bucket beside and only two type linked. For milk storage, four properties had tank immersion type and six type expansion. In relation to the equipment for heating water of milking machine sanitization and utensils, only two properties had this equipment. 
The group of medium technological standard was composed of eight properties, which had intermediate characteristics to other groups. These properties herds were composed of animals more specialized and with presence of pure animals, when compared to the group of low technological standard. The animals feed was pasture-based with predominance of supplementation of concentrate and silage throughout the year. Among the properties of this group, 6 had canalized milking machines and two bucket beside (same proportion verified for the heating of water equipment). Regarding the refrigeration tank type, all had expansion tank type. Some of the equipment used by these properties were similar to those of the properties of high technological standard, but were less sophisticated and had a shorter life span.

The variables analyzed were the levels of protein and fat, in addition to the somatic cell count (SCC) and total bacterial count (TBC). The evaluated parameters related to analyzes provided monthly by dairy producers were used where the quarterly average of the quality parameters of the months of February, March and April 2013, obtained of at least two monthly collections. For the determination of protein and fat, an infrared technique was used, reference with following methodology described by International Dairy Federation (2000). For the determination of CCS and CBT the flow cytometry technique was used, following the method described in ISO 21187/International Dairy Federation (2004) for TBC and ISO 13366-2/International Dairy Federation (2006) for CCS.

A completely randomized design (CRD) was used, which were submitted to analysis of variance and the means were compared by Tukey's test $(\mathrm{p}<0.05)$, by Sisvar software version 5.1 Build 72 (FERREIRA, 2011). The data were also subjected to methods of multivariate statistical analysis, following the procedures indicated by Ter Braak \& Smilauer (1998). Initially, it was used from the analysis of Detrended Correspondence Analysis (DCA) to obtain the length of the gradient. As the gradient length was less than three (0.399) meant that each variable has assumed a linear response in relation to the axle (gradient) (LEPS; SMILAUER, 1999). In this case, indicates the use of the Principal Component Analysis (PCA) for the groups separation evaluated. In this way, the PCA was used with the objective of checking if there is any difference between the groups, as well as analyze the relationship of these variables using the answers, giving equal emphasis to them all at the same time. The principal component analysis is an indirect gradient analysis that begins with a normal ordering where the values (coordinates) of a particular axis can be interpreted as gradient of an explanatory variable (TER BRAAK; SMILAUER, 1998). It was also the Redundancy Analysis (RDA), to test the relation between the variables answers with the explanatory variables selected. The redundancy analysis is an ordination of data of response of direct gradient in which the axes are built to be linear combinations of response variables, used to detect and predict the underlying structure of data based on explanatory variables. The explanatory variables are not directly used to predict the differences between treatments, but are added to help answer the obtained data. For this, the RDA analysis employed, initially, all the explanatory variables selected for the template and was performed with the data processed in accordance with the equation: $\mathrm{x}=\log (\mathrm{x}+1)$ (TER BRAAK; SMILAUER, 1998).

In this way, indicators were used related to production technologies, to identify which variables were the most important in the explanation of the results. The explanatory variables were selected considering those that could relate to the parameters of milk quality, such as: perform pre and/or postdipping; type and capacity of the tank for cooling the milk; type of milking; frequency of milk collection; performs disinfection of equipment before the animals mechanical milking; uses alkaline detergent and/or acid; presence of equipment for heating the sanitizing water of utensils/milking; cleaning of ceilings with tap water; use of paper towel on the drying of the teats; elimination of first three milk streams before the milking (mug test); performance of the CMT (California Mastitis Tests) test; performance of therapy for dry cow; Pass-through for verification of residual milk; predominance of genetic group of animals; type of feeding (pasture or not) and amount of concentrate supplied by animal day ${ }^{-1}$.

Due to the absence of significance measure through permutations by Monte Carlo test and the existence of collinearit of some variables measured through the analysis of Inflation Factor, was performed a Forward Selection, keeping only the most significant variables for the analysis, which were:

a) HBA: Holstein breed animals. Indicates the percentage of participation of this breed on herd on lactation period. The variable is ordinal and assumes a value for properties that have up to $25 \%$ of the Holstein herd, two for property that have of (between) 25.1 to $50 \%$, three for properties that have of 50.1 to $75 \%$ and four for properties that 
have from 75.1 to $100 \%$ of the animals of the Holstein breed.

b) PDES: Pre-disinfection of the teat cup rubbers set. Indicates whether it was performed on the property the equipment sanitization (set of teat cup rubbers) before the process of mechanical milking. The variable is binary (dummy) and accepts value one for the properties that perform the handling and zero for those who do not.

c) MT: Mug Test: Indicates whether it was performed discard the first three streams of milk before the beginning of the milking as form of mastitis diagnosis. The variable is binary (dummy) and accepts value one for the properties that perform the mug test and zero for those who do not.

d) EHW: Equipment for heating water. Indicates if the property used equipment heating water of sanitization of milking equipments The variable is binary (dummy) and accepts value one for the properties that have the equipment and zero for those that do not have.

e) POSD: Post-dipping. Indicates whether it was performed the handling of disinfecting teats after milking. The variable is binary (dummy) and accepts value one for the properties that perform and zero for those that do not perform.

f) AC: Amount of concentrate. Indicates the amount of concentrate provided per animal/day. The variable is an ordinal and assumes value one for properties that provide up to $3.0 \mathrm{~kg}$ of concentrate/cow/day; two for those who provide from 3.1 to $6.0 \mathrm{~kg}$ of concentrate/cow/day; three for those that provide 6.1 to $9.0 \mathrm{~kg}$ of concentrate/cow/day and four for the properties that provide above $9.1 \mathrm{~kg}$ of concentrate/cow/day.

\section{RESULTS}

The preliminary results of the Principal Component Analysis (PCA) demonstrated that the shaft one explained $51.9 \%$ of the data variability, and the axles two, three and four explained, respectively, $25.6 \%, 20 \%$ and $2.5 \%$, of the total data variability on four dimensions. The axes one and two together explain $77.5 \%$ of the total variability of accumulated data. The eigenvalue for the four dimensions was $0.519,0.256, \quad 0.20$ and 0.025 , respectively (Figure 1).

Figure 1 represents the average value of principal components represented through the centroids. The Principal Component Analysis biplot graphic shows a clear separation between the groups evaluated (Low, Medium and High). This indicates, whereas the axis one, a separation between the groups of properties with medium and high technological standard group of low technological standard. To analyze the axis two of the PCA, the same behavior was observed, in which there was separation between the group of properties of low technological standard from the other. Note that the groups of middle and high technological standard showed no separation by any of PCA axis, indicating strong association between both. It also shows the association of parameters of fat (\%), protein (\%) and TBC $(\mathrm{CFU} / \mathrm{ml})$ with the group of low technological standard. In the analysis interpretation, this indicates that the higher values of these parameters are associated with the group of low technological standard. Unlike this behavior, the groups of middle and high technological standard, showed lower values, which demonstrated that as increased the technological standard of properties, decreased the levels of solids and the TBC in milk. When analyzed the variable (SCC cells $/ \mathrm{ml}$ ), it was observed that the same had no association with any of the analyzed groups.

The results obtained by the variance analysis showed similar behavior to the one presented in PCA. Thus, it has been found that the properties of low technological standard showed higher levels of fat in the milk $(\mathrm{p}<0.05)$, followed by middle and high level that does not differ from each other $(p>0.05)$. The levels of protein were higher in low standard with respect to medium $(\mathrm{p}<0.05)$, being that the high standard of technology does not differ from the other treatments $(p>0.05)$. The TBC of properties of low technology presented the highest values when compared to the other treatments $(\mathrm{p}<0.05)$ while the SCC showed no difference between the groups ( $\mathrm{p}>0.05)$ (Table 1).

It is observed in the Table 1, that the group of technological standard low presented values of TBC above the average of the other groups and also of the maximum limit allowed by NI 62/2011, what points low microbiology quality of the milk produced by these properties. With relationship to the protein tenors and fat, all the groups presented values above the minimum demanded by $\mathrm{NI}$ $62 / 2011$, however it was observed in the properties of low technological standard larger quality of these parameters, which were superior to the other groups, mainly the fat. 


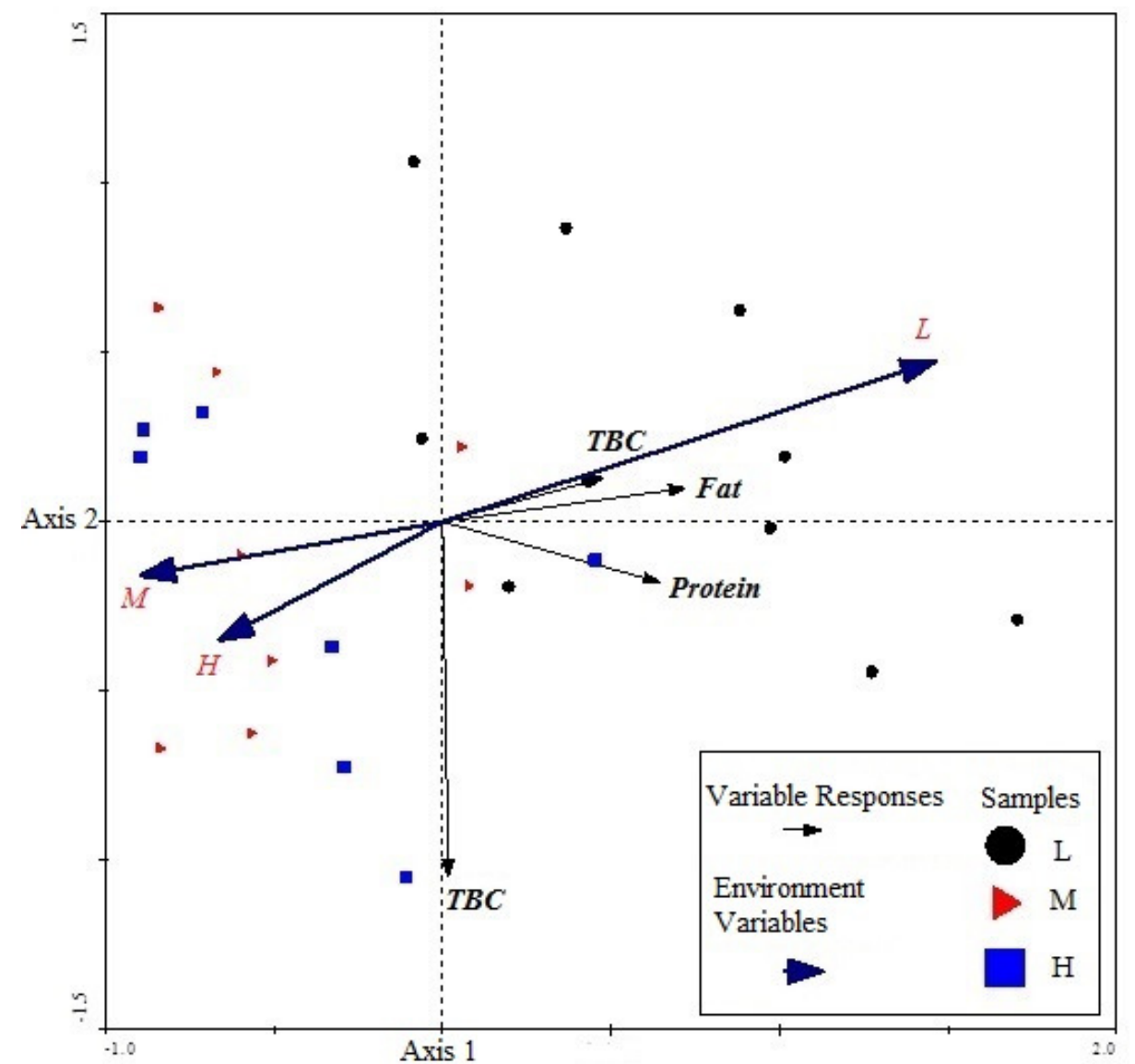

Figure 1. Biplot Graphic of variable responses (protein (\%), fat (\%), somatic cell count (cells/mL) and total bacterial count $(\mathrm{CFU} / \mathrm{mL})$ ) through the analysis of the main components in the plan defined by dimensions one and two and average value of main components represented through the centroids of the analyzed groups (L - Low, M - Medium and H - High technological standard ).

Table 1. Mean and Standard Deviation of the quality parameters of milk groups contrasted.

\begin{tabular}{l|cccc}
\hline \multirow{2}{*}{ Variables } & \multicolumn{4}{|c}{ Technological Standard $(\boldsymbol{\mu} \pm \boldsymbol{\sigma})$} \\
\cline { 2 - 5 } & Low & Middle & High & $*$ NI 62 \\
\hline Fat $(\%)$ & $4.43^{\mathrm{a}} \pm 0.49$ & $3.63^{\mathrm{b}} \pm 0.28$ & $3.72^{\mathrm{b}} \pm 0.37$ & 3.0 (Min.) \\
Protein $(\%)$ & $3.37^{\mathrm{a}} \pm 0.24$ & $3.07^{\mathrm{b}} \pm 0.16$ & $3.21^{\mathrm{a}^{\mathrm{b}} \pm 0.18}$ & 2.9 (Min.) \\
SCC $($ cells/ml) & $316.150^{\mathrm{a}} \pm 118.66$ & $401.660^{\mathrm{a}} \pm 153.37$ & $424.500^{\mathrm{a}} \pm 222.21$ & 600.000 (Max.) \\
TBC $($ CFU/ml) & $749.600^{\mathrm{a}} \pm 684.49$ & $107.900^{\mathrm{b}} \pm 76.05$ & $38.850^{\mathrm{b}} \pm 36.20$ & 600.000 (Max.) \\
\hline
\end{tabular}

Values followed by same letter on line do not differ among themselves by Tukey test $(\mathrm{p}<0.05)$.

* Parameters of milk quality required by Normative Instruction 62 of December 29, 2011, for the period from 01.01.2012 to 06.30.2014, in regions South /Southeast/Center-west (BRAZIL, 2011).

The Analysis of Redundancy (RDA) without the explanatory variables explained $51.9 \%$ of the data and when we analyzed all the selected variables, the model explained $100 \%$ of the total variability of the data, being $68.3 \%$ in shaft a and $18.2 \%$ in two axis (Figure 2). Whereas the model with only the explanatory variables significant and not collinear, the model explained $64.3 \%$ of the total variability of the milk quality parameters. Of these, $43.9 \%$ are represented on axis one and $11.8 \%$ on axis two. Together, the dimensions one and two explain
$55.7 \%$ of the relationship between explanatory variables and responses.

The permutation test of Monte Carlo showed significant effect for the selected model $(\mathrm{F}=5,411 ; \mathrm{p}=0.0020)$, which indicates that there is no relationship between the explanatory variables and the responses. The test also determined the percentage of explanation of each explanatory variable selected, being that the variable HBA alone explained $27.93 \%$ of the data variability. Next to it, are the variables EHW (13.99\%), AC (6,30\%), MT $(5,61 \%)$, PDES $(5.29 \%)$ and POSD (5.22\%). In 
general, the axis one of the RDA shows great separation between the explanatory variables HBA $(p=0.002), \quad \mathrm{AC} \quad(\mathrm{p}=0.060)$, EHW ( $p=0.004)$ and PDES $(p=0.104)$ with the protein parameters, fat and $\mathrm{TBC}$, i.e. indicates high correlation and negative between such explanatory variables and responses.

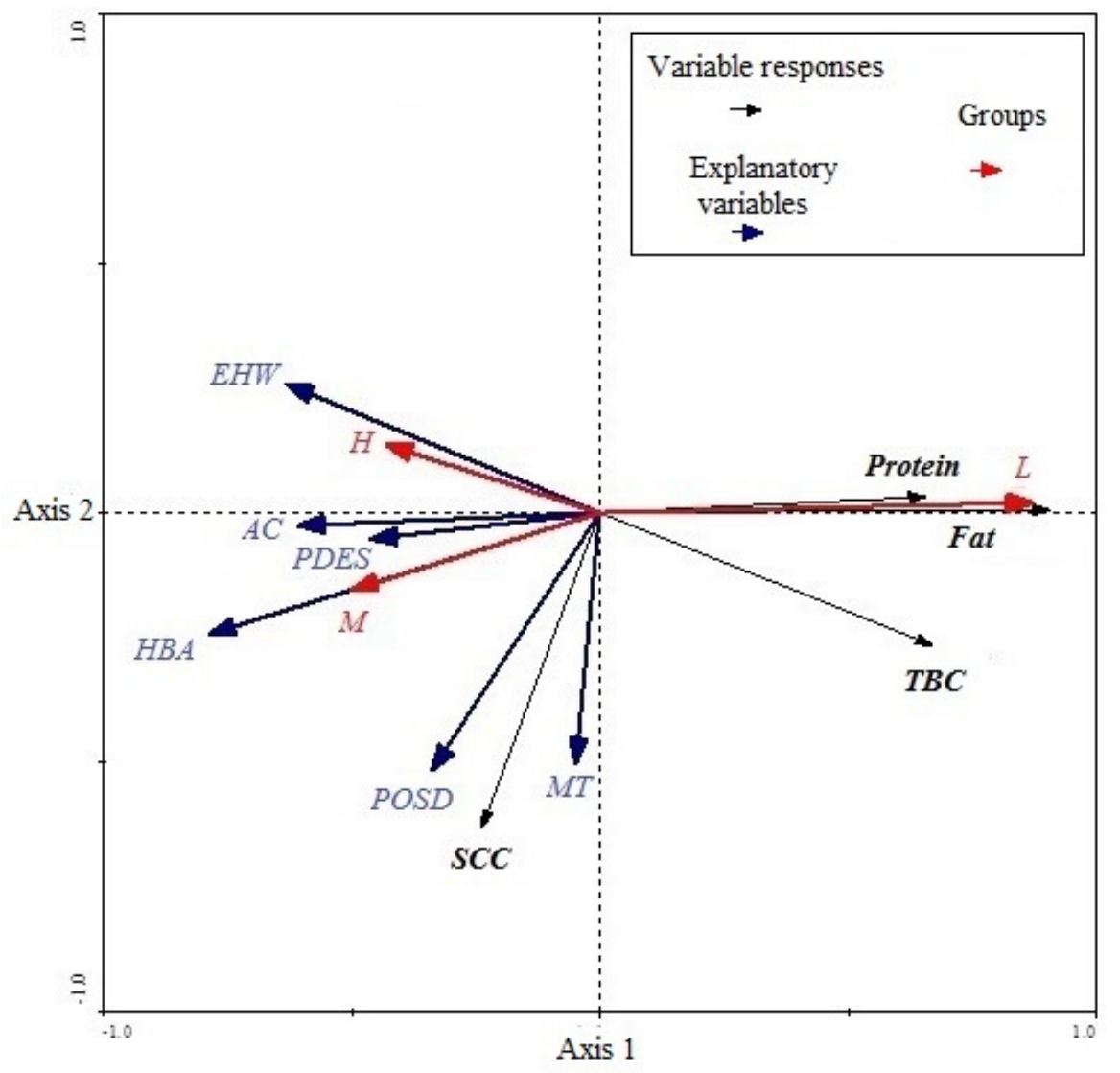

Figure 2. Triplot Analysis of Redundancy (RDA) between the response variables (protein (\%), fat (\%), somatic cell count (cells/ml) and total bacterial count $(\mathrm{CFU} / \mathrm{ml})$ for groups ( $\mathrm{L}$ - Low, $\mathrm{M}$ - Medium and $\mathrm{H}$ - High technological standard) and explanatory variables (HBA - Animals of Holstein breed; PDES - Pre-Disinfection of Milking; AQE - Use of equipment for heating water; POSD - Postdipping; MT - Mug Test; AC - Amount of concentrate ( $\mathrm{kg} / \mathrm{cow} /$ day).

Through the PDA it was observed that the SCC was not associated with any of the groups. Despite this, the RDA indicated highly significant correlation between the explanatory variables MT mug test $(\mathrm{p}=0.062)$ and POSD - postdipping $(\mathrm{p}=0.088)$ with the variable SCC.

\section{DISCUSSION}

The variation in the parameters of milk quality between properties of different technology levels was also observed by several authors. In work performed by Araujo (2011) and Dotto et al. (2012) it was observed that as increased the technological level of properties there has been a drop in levels of protein and fat, as well the values of TBC and SCC.

Analyzing the quality of milk of properties with different levels of expertise, Zanela et al.
(2006) found lower levels of protein and fat and milk SCC in more specialized properties. Similar results were also found by, Simioni et al. (2013), where there has been decrease in solids content (protein and fat) and values of TBC and SCC, as increased the level of expertise of the properties.

All the authors cited above attributed the racial pattern of animals as the main cause of the difference in levels of milk protein and fat content. The solids content of the milk are changed by several factors, such as breed, the animals power and productivity, and according to Nornberg (2003) the breed pattern is the factor that most influences the milk levels of protein and fat. Yet, according to this author, Ribas et al., (2004) it is affirmed that this variation occurs $55 \%$ of animals genetic origin and $45 \%$ of environmental origin. The 
influence of genetics of animals is more noticeable when comparing animals with Holstein breed zebu animals, mainly in the milk fat parameter, being approximately $4.39 \%$ and $3.32 \%$ respectively (GALVÃO JUNIOR, 2010). According to Madalena et al. (1990) as increases the proportion of genetic Holstein breed in animals, decreases the levels of milks protein and fat content.

In this study, the measurement of the influence of racial pattern of animals occurs by the animals participation in lactation of Holstein breed (HBA). The analysis of RDA allowed us to verify that the variable HBA presented opposite behavior to protein and fat levels, being observed its separation, both by axis one and two of the RDA. The average percentage of lactating animals Holstein breed in herds was $76 \%$ and $89 \%$ for the medium and high technology groups, respectively. In the group of low technology, five properties possessed no animals of the Holstein breed, being that in other properties of this is group, the average was $43 \%$. Similar behavior was described by Milani (2011) in which in properties of high technological standard were observed greater use of animals pure breeds, predominantly Holstein breed.

Before this, the greater presence of animals Holstein bred in groups of middle and high technological standard explains the lower contents of solids found, when compared to the properties of low technological standard, which showed predominance of animals of Jersey breed and/or crossover. In Zanela et al. (2006) work, differences in solids levels of milk between animals of Holstein breed and Jersey were $3.09 \pm 0.39$ and $4.10 \pm 0.64 \%$ fat and $3.02 \pm 0.15$ and $3.42 \pm 0.26 \%$ for protein, respectively. In Deitos, Maggioni \& Romero (2010) and Reis et al. (2012) work, it was found that animals of Holstein breed showed lower levels of protein and fat when compared to other dairy breeds, pure or cross-subsidization.

According to Lopes et al. (2009) work, as increased the technological level of properties, the costs of production also increased (mainly fixed costs), which leads the properties to seek greater productivity and efficiency. This is one of the factors that justify the greater use of Holstein breed in groups of middle and high technological standard, once that among the breeds specialized in milk production, the Holstein breed provides higher milk production per lactation period, provided that they are offered nutritional conditions and adequate environmental. Another factor, is that animals Holstein breed are large and require greater nutritional intake, which would have some limitation the properties of low technological standard, which had few resources, such as available area, supplementation, infrastructure, among others. Thus, in these conditions, animals of Jersey breed is better suited.

It was also observed in the RDA, that the variable amount of concentrate (AC) showed the same behavior as the variable Holstein breed, i.e. had opposite behavior to solids levels. In low technological standard, three properties did not provide concentrated for the animals. Considering only the properties that were provided, the average was $2.21 \pm 0.75 ; \quad 4.15 \pm 1.16$ and $\quad 10.71 \pm 3.19$ (kg/animal/day) for low technology levels, medium and high, respectively.

According to Ashes, Gulati \& Scott (1997), the change of voluminous:concentrate relation the diet is one of the factors linked to the reduction of the fat synthesis in the milk. The theory, more currently accepted, which explains the decrease of fat in milk, refers to isomers of conjugated linoleic acid (CLA), which are derived from the partial ruminal biohydrogenation, caused by a change in pattern of rumen fermentation. These isomers inhibit the synthesis of new in mammary gland and thus, the fat level $\Delta$ in milk (BAUMAN; GRIINARI, 2003). The increase of trans-fatty acids in milk fat is commonly observed in diets of dairy cows with low voluminous relation: concentrate (BAUMAN; GRIINARI, 2001). A study done by Piperova et al. (2000), comparing diets with different voluminous:concentrate relation, it was observed that in the diet of smaller voluminous:concentrate relation was reduced to $43 \%$ of the fat milk. There was also a reduction of enzymes acetyl-CoA carboxylase $(61 \%)$ and fatty acid synthetase $(44 \%)$, which are involved with the milk fat synthesis. In a way, along with the animals breed pattern, this theory can explain the lower levels of fat milk found in the properties of medium and high technological standard.

The SCC is an indicator of milk quality and the health of the mammary gland. It is composed by all the cells present in milk, including the cells of desquamation of the epithelium of the mammary gland and the organism defense cells, the leukocytes (NATZKE, 1981). The SCC of healthy animals is presented by around 300,000 cells $/ \mathrm{mL}$ being that values above these indicate health and hygienic milk problems (FONSECA; SANTOS, 2000). The main factor that affects the SCC is the presence of infection in the mammary gland (mastitis) that occurs by the invasion of micro-organisms (SANTOS, 2003), which results in the increase of 
the animal defense cells in the milk (somatic cells) (PASCHOAL; ZANETTI; CUNHA, 2003).

In this research, the SCC showed no difference between the groups contrasted, which indicates that this variable was linked to factors not inherent in technological standard and yes associated with the animal, as the presence of mammary gland (mastitis) infections and stage of lactation. Generally, it was found in the RDA that properties that presented higher values of SCC in milk were the ones that most have adopted the practice of milking post-dipping and mug test. The use of these two handlings, possibly occurs by the benefits that they bring in the diagnosis and prevention of bovine mastitis, once that the mastitis is largely responsible for the increase of SCC in milk. This behavior brings the idea that many producers only goes after prevention practices and the mastitis diagnosis, only when already the problem is there.

According to Coser et al. (2012) the postdipping is the more relevant isolated practiced in control of new mastitis cases, being that this handling can be efficient, must immerse at least two-thirds of the teat in disinfectant solution. The mug test is one of the most used methods in the diagnosis of clinical mastitis, because this changes occur visible characteristics of milk secretion (PASCHOAL; ZANETTI; CUNHA, 2003). This explains the greater use of this practice by the properties that had high SCC. Another method used in the mastitis diagnosis is the California Mastitis Test (CMT), which diagnoses the degree of infection of each breast quarter, both of clinical mastitis, as of subclinical (DIAS, 2007). However, the CMT realization was little used by producers, which argue that such test is laborious.

The TBC represents the milk microbiological quality, being indicator of the animal hygiene, the environment and equipment. In the field, the packaging of animals in clean environment, maintenance and suitable hygienization of milking equipment and utensils and milker cleaning hands, are fundamental handlings for the microbial load of milk reduction (FONSECA; SANTOS, 2000). Through the redundancy analysis, we observed high and negative correlation between the TBC variable response and the explanatory EHW (use of water heating equipment) and the PDES (milking predisinfection). The use water heating equipment was observed in only $20 \%$ of the properties of low technological standard, while the medium and high encryption levels showed $75 \%$ and $86 \%$ respectively.

In practice, the use of hot water results in decreased microbial adhered on the surface of the equipment and consequent the TBC of milk. The use of this equipment also ensures adequate water temperature, which accordingly to Germano e Germano (2001), this maximizes the action of detergents, in addition to avoid proteins denaturation (very hot water) and the solidification of fats (cold water) on equipment surfaces (teat rubbers, hoses, cooling tank). Besides the denaturation of proteins the use of very hot water in the hygiene of equipment, induces polymerization of fat milk (FRESCO, 2002), such a fact that may reduce the efficiency of pre-disinfection of milking for example. Winck e Neto (2009) reported that the use of heated water, at approximately $70^{\circ} \mathrm{C}$, allows the maximum efficiency of chlorinated alkaline detergent, being that in ambient temperature the efficiency is very low. In the study conducted by these authors, only $36 \%$ of properties use hot water when washing milking equipment/utensils.

In the case of pre-disinfection (PDES) variable, this indicated the properties numbers that perform sanitization of all milking before animals mechanical milking. It was observed that only half of the properties of low technological standard performed the practice, while that in the medium and high technological standard proprieties was $75 \%$ and $100 \%$, respectively. It is worth noting that the majority of the groups properties of middle and high technological standard performed the practice daily a fact not noted in the group of low technological standard. In this way, the predisinfection handling contributes to reduce the microbial load of equipment between a milking and another, such fact that culminated with the association with the lowest levels of milk TBC of properties that were performing the practice.

\section{CONCLUSIONS}

The properties technological standard influenced the parameters of protein, fat and TBC, showing that as increased the properties technological level, there was a decrease in these parameters, except that SCC didn't show the same behavior, not being influenced by technological standards.

The variations in of protein and fat levels in milk were explained by animals breed pattern and by the amount of concentrate fed to animals.

The TBC was influenced by the milking hygiene practices, such as pre-disinfection of the 
Milk quality of properties...

milking system and the use of hot water of sanitization of equipment.

\section{ACKNOWLEDGMENTS}

ROZA, L. F. et al.

To the State University of Santa Catarina UDESC/CEO, for rural producers and to teachers and students of UDESC/CEO who helped with study realization.

RESUMO: Objetivou-se com este trabalho avaliar os parâmetros de qualidade do leite de propriedades com diferentes padrões tecnológicos. Foram analisadas 25 propriedades de 7 municípios da região Oeste de Santa Catarina, as quais foram classificadas de acordo com tecnologias de produção (alimentação, reprodução e práticas de manejo em geral), capital utilizado na atividade, padrão tecnológico de maquinários, equipamentos e infraestrutura. Foram classificadas 10 propriedades como de baixo padrão tecnológico, 8 de padrão intermediário e 7 de alto padrão tecnológico. Os dados de qualidade do leite de cada propriedade (gordura, proteína, contagem de células somáticas e contagem bacteriana total) foram fornecidos pelos lacticínios, sendo utilizada a média dos meses de fevereiro, março e abril. Os dados foram submetidos à análise estatística multivariada e de variância. Verificou-se que as propriedades de baixo padrão tecnológico apresentaram maiores teores de gordura no leite, seguido pelos padrões intermediário e alto que não diferiram entre si. Os teores de proteína foram maiores nas propriedades de baixo padrão em relação ao padrão intermediário, sendo que o padrão alta tecnologia não diferiu dos demais grupos. Com relação à CBT, as propriedades de baixa tecnologia apresentaram maiores valores quando comparado aos demais grupos, enquanto que a CCS não diferiu entre os diferentes padrões tecnológicos. Conclui-se que o padrão tecnológico das propriedades influenciou os parâmetros de proteína, gordura e CBT, sendo que conforme aumentou o nível tecnológico das propriedades, houve queda nestes parâmetros, com exceção da CCS que não apresentou mesmo comportamento, não sendo influenciada pelos padrões tecnológicos. As variações nos teores de proteína e gordura do leite foram explicadas pelo padrão racial dos animais e pela quantidade de concentrado fornecida aos animais. A CBT foi influenciada por práticas higiênicas na ordenha, como a pré-desinfecção do sistema de ordenha e a utilização de água quente na higienização dos equipamentos.

PALAVRAS-CHAVE: Bovinocultura leiteira. Tecnologias de produção.

\section{REFERENCES}

ARAÚJO, F. O. Qualidade do leite produzido nos meses de inverno e verão na região central do Rio Grande do Sul em diferentes níveis tecnológicos. 2011. 48p. Dissertação (Mestrado em Produção Animal) Universidade Federal de Santa Maria, Santa Maria, 2011.

ASHES, J. R.; GULATI, S. K.; SCOTT, T. W. Potential to alter the content and composition of milk fat through nutrition. Journal of Dairy Science, v. 80, n. 9, p. 2204-2212, 1997.

http://dx.doi.org/10.3168/jds.S0022-0302(97)76169-1

BAUMAN, D. E.; GRIINARI, J. M. Regulation and nutritional manipulation of milk fatty: low-fatty milk syndrome. Livestock Production Science. v. 70, p. 15-29, 2001. http://dx.doi.org/10.1016/S03016226(01)00195-6

BAUMAN, D. E.; GRIINARI, J. M. Nutritional regulation of milk fat synthesis. Annual Review of Nutrition, v. 23, n. 1, p. 203-227, 2003. http://dx.doi.org/10.1146/annurev.nutr.23.011702.073408

BRASIL. Ministério da Agricultura, Pecuária e Abastecimento. Instrução normativa nº2, de 29 de dezembro de 2011. Diário Oficial da República Federativa do Brasil, Brasília, DF, 30 de dezembro de 2011. Seção 1, p. $10-14$.

COSER, S. M.; LOPES, M. A.; COSTA, G. MÁRCIO. Mastite bovina: controle e prevenção. Lavras, MG. Universidade Federal de Lavras - Editora UFLA. Boletim Técnico, n. 93, p. 1-30, 2012.

DEITOS, A. C.; MAGGIONI, D.; ROMERO, E. A. Produção e qualidade de leite de vacas de Diferentes grupos genéticos. Revista Campo digital, Campo Mourão, v. 5, n. 1, p. 26-33, dez. 2010. 
DIAS, R. V. C. Principais métodos de diagnósticos e controle da mastite bovina. Acta Veterinária Brasílica, Mossoró, v. 1, n. 1, p. 23-27, 2007.

DOTTO, L. R.; VIÉGAS, J.; MORO, G.; COSTA, L. P.; PEREIRA, S. N. Qualidade do leite produzido região central do Rio Grande do Sul em diferentes níveis tecnológicos. In: XV FÓRUM DE PRODUÇÃO PECUÁRIA-LEITE, 15., 2012, Cruz Alta. Anais... Cruz Alta: II Salão de trabalho científicos, 2012. p. 275280.

FERREIRA, D. F. Sisvar: a computer statistical analysis system. Revista Ciência e Agrotecnologia, Lavras, v. 35, n. 6, p. 1039-1042, 2011.

FONSECA, A. G. N.; SANTOS, M. V. Qualidade do leite e controle de mastite. São Paulo: Lemos editorial, 2000, 175p.

FRESCO, J. P. Ingeniería, Autocontrol y Auditoria de la Higiene en la Industria Alimentaria. Espanha: Ediciones Mundi - Prensa, 2002.

GERMANO, P. M. L.; GERMANO, M. I. S. Higiene e vigilância sanitária de alimentos. 1. ed. São Paulo: Varela, 2001, 629p.

GALVÃO JÚNIOR, J. G. B. G.; RANGEL, A. H. N.; MEDEIROS, H. R.; SILVA, J. B. A.; AGUAIR, E. M.; MADRUGA, R. C.; LIMA JÚNIOR, D. M. Efeito da produção diária e da ordem de parto na composição físico-química do leite de vacas de raças zebuínas, Acta Veterinária Brasílica, Mossoró, v. 4, n. 1, p. 25-30, 2010.

INTERNATIONAL DAIRY FEDERATION (IDF) 141C - Determination of milkfat, protein and lactose content - Guidance on the operation of mid-infrared instruments. Brussels, Belgium, 2000. 15p.

INTERNATIONAL DAIRY FEDERATION. 196 - ISO 21187 - Milk - Quantitative determination of bacteriological quality - Guidance for establishing and verifying a conversion relationship between routine method results and anchor method results. Brussels, Belgium, 2004. 13p.

INTERNATIONAL DAIRY FEDERATION. 148-2 - ISO 13366-2 - Milk - Enumeration of somatic cells Part 2: Guidance on the operation of fluoro-opto-electronic counters. Brussels, Belgium, 2006. 15p.

LEPS, J.; SMILAUER, P. Multivariate analysis of ecological data using CANOCO. Ceské Budejovice: University of South Bohemia, 1999.

LOPES, M. A.; DIAS, A. S.; CARVALHO, F. M.; LIMA, A. L. R.; CARDOSO, M. G.; CARMO, E. A. Resultados econômicos de sistemas de produção de leite com diferentes níveis tecnológicos na região de Lavras MG nos anos 2004 e 2005. Revista Ciência e Agrotecnologia, Lavras, v.33, n.1, p.252-260, 2009.

MATTAR, F. N. Pesquisa de marketing. São Paulo: Atlas, 2001.

MADALENA, F. E.; LEMOS, A. M.; TEODORO, R. L.; BARBOSA, R. T.; MONTEIRO, J. B. N. Dairy production and reproduction in Holstein-Friesan x Guzera crosses. Journal of Dairy Science. v. 73, p. 18721886, 1990. http://dx.doi.org/10.3168/jds.S0022-0302(90)78868-6

MILANI, M. P. Qualidade do leite em diferentes sistemas de produção, anos e estações climáticas do noroeste do Rio Grande do Sul. 2011. 67p. Dissertação (Mestrado em Ciência e Tecnologia de Alimentos) Universidade Federal de Santa Maria, Santa Maria, 2011.

NATZKE, R. P. Elements of mastitis control. Journal of Dairy Science. v. 64, p. 1431-1442. 1981. http://dx.doi.org/10.3168/jds.S0022-0302(81)82713-0 
NORNBERG, J. L. Efeito de diferentes fontes de gordura na dieta de vacas Jersey na fase inicial de lactação. 2003. 174p. Tese (Doutorado em Zootecnia) - Universidade Federal do Rio Grande do Sul, Porto Alegre, 2003.

OLIVEIRA, A. S.; CUNHA, D. N. F. V.; CAMPOS, J. M. S. Identificação e quantificação de indicadoresreferência de sistemas de produção de leite. Revista Brasileira de Zootecnia, Viçosa, v. 36, n. 2, p. 507-516, 2007.

OHI, M.; KNOPI, A. C. G.; BEDNARSKI, F.; SILVA, L. B.; NASCIMENTO, L. V.; Princípios básicos para a produção de leite bovino. Curitiba: Imprensa da UFPR, 2010. 144p.

PASCHOAL, J, J.; ZANETTI, M. A.; CUNHA, J. A. Suplementação de selênio e vitamina E sobre a contagem de células somáticas no leite de vacas da raça Holandesa. Revista Brasileira de Zootecnia, Viçosa, v. 32, n. 6, p. 2032-2039, 2003 (Suplemento 2).

PIPEROVA, S. L.; B. TETER, B. B.; BRUCKENTAL, I.; SAMPUGNA, J.; MILLS, S. E.; MARTIN P. YURAWECZ., FRITSCHE, J.; KU, K.; ERDMAN, R. A. Mammary lipogenic enzyme activity, trans fatty acids and conjugated linoleic acids are altered in lactating dairy cows fed a milk fat-depressing diet. Journal of Nutrition, v. 130, p.2568-2574, 2000.

REIS, A. M.; COSTA, M. R.; COSTA, R. G.; SUGUIMOTO, H. H.; SOUZA, C. H. B.; ARAGON-ALEGRO, L. C.; LUDOVICO, A.; SANTANA, E. H. W. Efeito do grupo racial e do número de lactações sobre a produtividade e a composição do leite bovino. Semina: Ciências Agrárias, Londrina, v. 33, p. 3421-3436, 2012. (Suplemento 2).

RIBAS, N. P.; HARTMANN, W.; MONARDES, H. G.; ANDRADE, U. V. C. Sólidos totais do leite em amostras de tanque nos estados do Paraná, Santa Catarina e São Paulo. Revista Brasileira de Zootecnia, Viçosa, v. 33, n. 6, p. 2343-2350, 2004. (Suplemento 3).

RIBEIRO, M. E. R.; STUMPF JÚNIOR, W.; BUSS, H. Qualidade de leite. In: BITENCOURT, D.; PEGORARO, L. M. C.; GOMES, J. F. Sistemas de pecuária de leite: uma visão na região de Clima Temperado. Pelotas: Embrapa Clima Temperado, 2000. p. 175-195.

SANTOS, M. V. Influência da qualidade do leite na manufatura e vida de prateleira dos produtos lácteos: papel das células somáticas. In: BRITO, J. R. F.; PORTUGAL, J. A. B. (Org.). Diagnóstico da qualidade do leite, impacto para a indústria e a questão dos resíduos de antibióticos. Juiz de Fora, v. 1, p. 139-149, 2003.

SIMIONI, F. J.; BARETTA, C. R. D. M.; STEFANI, L. M.; LOPES, L. S.; TIZZIANI, T. Qualidade do leite proveniente de propriedades com diferentes níveis de especialização. Semina: Ciências Agrárias, Londrina, v. 34, n. 4, p. 945-960, jul./ago. 2013.

TER BRAAK, C. J. F.; SMILAEUR, P. C. Reference manual and user's guide to CANOCO for windows: software for canonical community ordination (version 4), Ithaca, New York, USA, Microcomputer Power, 1998.

ZANELA, M. B.; FISCHER, V.; RIBEIRO, M. E. R.; JUNIOR STUMPF, W.; ZANELA, C.; MARQUES, L. T.; MARTINS, P. R. G. Qualidade do leite em sistemas de produção na região Sul do Rio Grande do Sul. Pesquisa Agropecuária Brasileira, Brasília, v. 41, n. 1, p. 153-159, 2006. http://dx.doi.org/10.1590/S0100204X2006000100021

WINCK, C. A., NETO, A. T. Diagnóstico da adequação de propriedades leiteiras em Santa Catarina às normas brasileiras de qualidade do leite. Revista de Ciências Agroveterinárias, Lages, v. 8, n. 2, p. 164-172, 2009. 